\title{
Reflexiones sobre la pensión de vejez y protección integral a la vejez en Colombia
}

\author{
Reflections on the old age pension and comprehensive protection \\ for the old age in Colombia \\ Judith Vanesa Galeano Buenaventura \\ Marilyn A. García Gallego ${ }^{2}$ \\ Natalia Eugenia Gómez Rúa
}

Fecha correspondencia:

Recibido: 3 de noviembre de 2020. Revisión: 9 de diciembre de 2020. Aceptado: 28 de mayo de 2021.

\section{Forma de citar:}

Galeano, Judith Vanesa; Marylin Andrea, García; Gómez, Natalia Eugenia. (2021). "Reflexiones sobre la pensión de vejez y protección integral a la vejez en Colombia." En: Revista CES Derecho. Vol. 12, №. 1, enero a junio de 2021, p. 126-153.

\section{Open access}

Términos de uso

Licencia creative commons

Etica de publicaciones

Revisión por pares

Gestión por Open Journal System DOl: https://dx.doi.org/10.21615/ cesder.12.1.7

ISSN: 2145-7719

Sobre los autores:

1. Abogada. Especialista en derecho laboral y relaciones industriales. Estudiante Maestría en Seguridad Social.

2. Trabajadora Social. Especialista en Gerencia de la Seguridad Social. Estudiante Maestría en Seguridad Social.

\section{Resumen}

La seguridad social como derecho, está llamado a satisfacer las necesidades mínimas que se presentan en las diferentes contingencias de la vida, entre ellas la vejez; el envejecimiento humano y el crecimiento exponencial del mismo generan la inminente necesidad de implementar medidas eficientes y eficaces por parte de los gobiernos del mundo para proteger a las personas mayores que se encuentran en estado de debilidad manifiesta. El desarrollo histórico de la seguridad social, la protección legal y constitucional a la vejez y los desafíos derivados de la COVID-19 en el sistema de seguridad social pensión, son un llamado a crear un sistema para la protección integral de la vejez en Colombia.

Palabras claves: seguridad social, personas mayores, pensión de vejez, protección integral a la vejez, COVID-19.

\section{Abstrract}

Social welfare as a right, is called upon to satisfy the minimum requirements that are presented in different contingencies of life, within these is old age. Human aging and its exponential growth generate the imminent necessity for world governments to implement efficient and effective measures to protect the elderly who are in a state of manifest weakness. The historical development of social welfare, the legal and constitutional protection to the elderly and the challenges arising from COVID-19 in the social security pension system, is a calling to create a system for the comprehensive protection for elderly adults in Colombia.

Keywords: Social welfare, elderly, security pension system, comprehension protection for elderly adults, COVID-19.

\section{Introducción}

La seguridad social tuvo sus inicios en las ideas propugnadas por el iluminismo y las revoluciones liberales del siglo XVIII que acabaron con los antiguos regímenes de la época y dieron paso a los denominados Estados liberales, reivindicando a los individuos frente al Estado, aunque esto implicara ceder su libertad para vivir en comunidad mediante un contrato social. 
3. Abogada. Especialista en Derecho de la Seguridad Social. Magister en Derecho. Doctora en Salud Pública.
No obstante en los estados liberales las pretensiones sociales inmersas en los derechos sociales eran incompatibles con las instituciones jurídicas y políticas de la época, no se encontraban dentro de las funciones del estado, siendo desplazadas a las personas particulares o instituciones privadas; como consecuencia de no asumir dichas pretensiones, con el transcurso de los años los Estados que habían dado ese paso a los ideales clásicos del liberalismo se encontraron en situaciones sociales y económicas deplorables, terminando por acoger las pretensiones sociales de la época como deberes del Estado.

Con los ideales del liberalismo clásico, nacen las primeras constituciones que ponen de manifiesto la función del Estado en pro de los derechos sociales: la mexicana de Querétano de 1917 y, la alemana de Weimar en 1919, siendo esta última la que consagra un seguro para la vejez, señala en el "Art. 161. - Para la conservación de la salud y la capacidad de trabajo, la protección de la maternidad y la previsión contra las consecuencias económicas de la vejez, de la debilidad y de las vicisitudes de la vida, creará el estado un comprensivo sistema de seguro bajo la decisiva cooperación de los asegurados." (Constitución del Imperio alemán, 1919)

En la actualidad, la seguridad social se ha entendido como el conjunto de derechos y deberes e, instrumentos públicos y privados tendientes a brindar a los seres humanos las garantías necesarias para la protección de derechos fundamentales, tales como la dignidad humana, la salud, mínimo vital y la vida misma, frente a los riesgos sociales que puedan afectar su capacidad para valerse de sí mismo y su núcleo familiar; bajo ese entendido en este artículo se pretende describir y analizar si el marco jurídico y los instrumentos implementados por los diferentes entes gubernamentales en pro de proteger a la vejez, han sido suficientes para garantizar la protección integral de la vejez.

En consecuencia, en un primer momento se presente una breve perspectiva histórica colombiana de la seguridad social y de la pensión de vejez como principal instrumento para la protección de la vejez; en un segundo momento se desarrollará el concepto de vejez, persona mayor y protección integral a la vejez, junto con las medidas adicionales adoptadas en pro de proteger a la vejez se analizará si las mismas son eficientes y eficaces para el fin que se busca; por último se señalará las medidas adoptadas por el Gobierno Nacional en pro de proteger a las personas mayores y se determinará si las mismas están llamadas a la protección integral de la vejez en Colombia.

\section{Perspectiva histórica de la seguridad social y la pensión de vejez}

Desde el ámbito del derecho internacional el derecho a la seguridad social es objeto de protección por parte de tratados, convenios, pactos internacionales y doctrina de carácter internacional que consagra principios, reglas y recomendaciones, los cuales se encuentran bajo la vigilancia y control de organismos internacionales creados por la Asamblea General de las Naciones Unidas. Al respecto es importante resaltar los siguientes instrumentos institucionales: 
Tabla 1. Marco normativo internacional.

\begin{tabular}{|c|c|c|}
\hline Año & Aspecto & Propósito \\
\hline 1919 & Tratado de Versalles & Creación Organización Internacional del Trabajo (OIT) \\
\hline 1919 & Constitución de la OIT & Órganos y funcionamiento de la OIT \\
\hline 1944 & Declaración de Filadelfia -OIT & $\begin{array}{l}\text { Se extiende medidas de seguridad social para } \\
\text { garantizar ingresos básicos }\end{array}$ \\
\hline 1945 & $\begin{array}{l}\text { Carta de las Naciones Unidas, } \\
\text { San Francisco }\end{array}$ & Se crea la Organización de Naciones Unidas (ONU) \\
\hline 1947 & $\begin{array}{l}\text { Carta Internacional } \\
\text { Americana de Garantías } \\
\text { Sociales, IX Conferencia } \\
\text { Internacional de Río de } \\
\text { Janeiro }\end{array}$ & $\begin{array}{l}\text { Se establecen los principios fundamentales para } \\
\text { proteger a los trabajadores y los derechos mínimos. }\end{array}$ \\
\hline 1948 & $\begin{array}{l}\text { Declaración Universal de los } \\
\text { Derechos Humanos, ONU }\end{array}$ & $\begin{array}{l}\text { Se declara la seguridad social como un derecho } \\
\text { y los derechos económicos, sociales y culturales, } \\
\text { indispensables para la dignidad y el libre desarrollo } \\
\text { de la personalidad. }\end{array}$ \\
\hline 1948 & $\begin{array}{l}\text { Declaración Americana de } \\
\text { los Derechos y Deberes } \\
\text { del Hombre, IX Conferencia } \\
\text { Panamericana, Bogotá. }\end{array}$ & $\begin{array}{l}\text { Los Estado americanos establecen que toda persona } \\
\text { tiene derecho a la seguridad social. }\end{array}$ \\
\hline 1950 & $\begin{array}{l}\text { I Congreso Iberoamericano de } \\
\text { Seguridad Social celebrado } \\
\text { en Barcelona }\end{array}$ & $\begin{array}{l}\text { Origen de la Organización Iberoamericana de } \\
\text { Seguridad Social (OISS) y creación de la secretaría: } \\
\text { Comisión Iberoamericana de seguridad social. }\end{array}$ \\
\hline 1954 & $\begin{array}{l}\text { Il Congreso Iberoamericano } \\
\text { de Seguridad Social } \\
\text { celebrado en Lima (Perú) }\end{array}$ & Se aprobó la carta Constitucional de la OISS \\
\hline 1955 & Convenio 102 & $\begin{array}{l}\text { Convenio sobre Seguridad Social. Parte V. Pensión } \\
\text { de Vejez }\end{array}$ \\
\hline 1966 & $\begin{array}{l}\text { Pacto Internacional de } \\
\text { Derechos Económicos, } \\
\text { Sociales y Culturales, PIDESC, } \\
\text { ONU }\end{array}$ & $\begin{array}{l}\text { Artículo 9. "Los Estados Parte en el presente Pacto } \\
\text { reconocen el derecho de toda persona a la seguridad } \\
\text { social, incluso al seguro social." }\end{array}$ \\
\hline 1982 & $\begin{array}{l}\text { Tratado de la Comunidad } \\
\text { Iberoamericana de Seguridad } \\
\text { Social. }\end{array}$ & $\begin{array}{l}\text { Tiene como objetivo favorecer e intensificar } \\
\text { el desarrollo del Convenio Iberoamericano de } \\
\text { Seguridad y del Convenio de Cooperación en } \\
\text { Seguridad Social, suscritos el } 26 \text { de enero de } 1978 \\
\text { en Quito. }\end{array}$ \\
\hline 2007 & $\begin{array}{l}\text { Convenio Multilateral } \\
\text { Iberoamericano de Seguridad } \\
\text { Social }\end{array}$ & $\begin{array}{l}\text { El Convenio pretende crear una conciencia de } \\
\text { ciudadanía iberoamericana, permitiendo coordinar } \\
\text { las legislaciones nacionales en materia de } \\
\text { pensiones. }\end{array}$ \\
\hline
\end{tabular}

Fuente: Elaboración propia a partir de los instrumentos internacionales.

En Colombia, derechos sociales como la seguridad social, tuvieron una evolución lenta y poco significativa durante el siglo XIX y XX, la primera referencia que se tiene de los mismos, la hizo el General Simón Bolívar, en su discurso de Angostura el 15 de febrero de 1819, discurso pronunciado al Congreso General de Venezuela en el acto de instalación, cuando dijo: "El sistema de Gobierno más perfecto es aquel que produce mayor suma de felicidad posible, mayor suma de seguridad social y mayor 
suma de estabilidad política." (Bolívar, S. 1819). Sin embargo, no se determinó en las posteriores siete Constituciones Políticas de Colombia, ni en la Constitución de 1886 , que las pretensiones sociales inmersas en los derechos sociales como la seguridad social, fueran competencia del Estado, dejándoles a los entes privados la tarea social; en adición las primeras normas de seguridad social están sólo dirigidas a proteger determinados servidores públicos. A modo de ejemplo se ilustran las siguientes:

Tabla 2. Normas relacionadas con la protección a los servidores públicos en pensiones.

\begin{tabular}{ll}
\hline Ley 29 de 1905 & $\begin{array}{l}\text { Régimen de pensiones a favor de los magistrados de la Corte Suprema de } \\
\text { Justicia y empleados civiles que hayan desempeñado cargos públicos por } \\
30 \text { años. }\end{array}$ \\
\hline Ley 23 de 1912 & $\begin{array}{l}\text { Pensiones a favor de las viudas e hijas solteras de quienes hayan } \\
\text { desempeñado el cargo de Presidente de la República. }\end{array}$ \\
\hline Ley 82 de 1912 & $\begin{array}{l}\text { Primera Caja de Previsión Social: Caja de auxilios en los Ramos Postal y } \\
\text { Telegráfico" }\end{array}$ \\
\hline Ley 75 de 1925 & Caja de Sueldos de Retiro de las Fuerzas Militares \\
\hline Ley 102 de 1927 & $\begin{array}{l}\text { Pensiones a favor de las viudas de los magistrados de la Corte Suprema de } \\
\text { Justicia y de tribunales con más de } 20 \text { años de servicio. }\end{array}$ \\
\hline
\end{tabular}

Fuente: (Galeano, 2020)

A partir del año 1945 se codificó el sistema de seguridad social mediante la Ley 6 (Congreso de la República de Colombia, 1945) prescribiendo los derechos a pensión, salud y riesgos profesionales de los trabajadores; en ese entonces se gestó un plan de pensiones mediante la creación de la Caja Nacional de Previsión Social (CAJANAL) y la instauración de otras cajas a nivel local que cubrían a los empleados del sector público.

En 1967 mediante Decreto 3041 de 1966 se aprueba el reglamento general del seguro social obligatorio de invalidez, vejez y muerte (Ministerio de Trabajo, 1966), volviendo obligatorio el aseguramiento y concediendo pensiones a los empleados privados, siendo delegada su administración al Instituto Colombiano de los Seguros Sociales (ICSS), que en 1977 cambiaría su nombre a Instituto de Seguros Sociales (ISS). El modelo de seguridad social - pensiones que se implantó era el de prima media (o de reparto con beneficio definido) en el que los trabajadores que se aseguraban realizaban un aportante, sus contribuciones iban a un fondo común el cual pagaba las mesadas de las personas que se iban pensionando, repartiendo los recursos de ese fondo entre los pensionados. Si bien la implementación del Régimen de Prima Media creó las bases para el desarrollo del sistema pensional, el mismo era inequitativo y tenía baja cobertura. (Galeano, 2020)

Posteriormente, en la Constitución Política de Colombia de 1991 se estableció que los derechos sociales son competencia del Estado, concretamente se indicó en el Capítulo II, artículo 42 hasta el 82, los derechos económicos, sociales y culturales, los cuales han venido evolucionado jurisprudencialmente con los postulados propuestos por la Honorable Corte Constitucional. En consecuencia, la actual Constitución Política de Colombia consagra el derecho a la seguridad social en su artículo 48 de la siguiente forma: 
"La Seguridad Social es un servicio público de carácter obligatorio que se prestará bajo la dirección, coordinación y control del Estado, en sujeción a los principios de eficiencia, universalidad y solidaridad, en los términos que establezca la Ley. Se garantiza a todos los habitantes el derecho irrenunciable a la Seguridad Social. El Estado, con la participación de los particulares, ampliará progresivamente la cobertura de la Seguridad Social que comprenderá la prestación de los servicios en la forma que determine la Ley. La Seguridad Social podrá ser prestada por entidades públicas o privadas, de conformidad con la ley. No se podrán destinar ni utilizar los recursos de las instituciones de la Seguridad Social para fines diferentes a ella. La ley definirá los medios para que los recursos destinados a pensiones mantengan su poder adquisitivo constante." (Constitución Política de Colombia, 1991)

En Colombia la seguridad social se rige por un conjunto de principios que tiene su origen en los diferentes modelos del papel del Estado y se encuentran contemplados en el artículo 2 de la Ley 100 de 1993, los cuales son: eficiencia, universalidad, solidaridad, integralidad, unidad y participación" (Congreso de la República de Colombia, 1993).

Desde el marco normativo, en el parágrafo del artículo 2 de la Ley 100 de 1993, se establece que: "La seguridad social se desarrollará en forma progresiva, con el objeto de amparar a la población y la calidad de vida." (Congreso de la República de Colombia, 1993). Este postulado se ha desarrollado de dos maneras: primero, impidiendo normas y jurisprudencias regresivas y; segundo, como un mandato con el fin de que haya mejores condiciones que las prescritas en normas y jurisprudencias vigentes (Corte Constitucional. Sentencia T 884 de 2006, M.P. Humberto Antonio Sierra Porto). El principio de progresividad y la prohibición concomitante de regresividad de este derecho también se encuentra consagrado en el Artículo 48 de la Constitución Política de Colombia de 1991, la cual establece que "El Estado, con la participación de los particulares, ampliará progresivamente la cobertura de la Seguridad Social (...)" (Constitución Política de Colombia, 1991).

A lo largo de la historia de la seguridad social en Colombia han existido varios tránsitos legislativos a los que ha estado sometida la denominada "pensión de vejez"; siendo la principal figura jurídica, dentro del ordenamiento jurídico, llamada a proteger a los colombianos considerados personas mayores. A continuación, se enuncian los elementos relevantes de la evolución de la pensión de vejez en el país.

\section{Aspectos relevantes de la pensión de vejez en Colombia}

La pensión de vejez es una prestación económica que se obtiene como resultado de haber laborado y realizado de forma concomitante un ahorro forzoso durante un determinado tiempo, bien sea mediante la figura de provisionalidad por parte de los empleadores, Caja o Sistema General de Seguridad Social. La Corte Constitucional argumenta que su finalidad directa es garantizar la concreción de los derechos fundamentales de las personas traducidos en la dignidad humana, el mínimo vital, la seguridad social y la vida digna. (T-398, 2013).

La creación del Sistema General de Pensiones, se implementó mediante la Ley 100 de 1993 y cambió las condiciones en que las personas podrían pensionarse, para ello estableció un régimen de transición para quienes tenían la expectativa de pensionarse con normas anteriores como Ley 33 de 1985, Ley 71 de 1988 y Decreto 758 de 990 y; especiales: DAS, Rama judicial, Ministerio Público, Aeronáutica civil, 
cuerpos de bomberos, Trabajo en minería, alta temperaturas, exposición a radiaciones y sustancias cancerígenas, INPEC y presidente de la república. Reconoce regímenes exceptuados como los miembros de las fuerzas militares y de la policía nacional, los afiliados al Fondo de Prestaciones Sociales del Magisterio, personal civil que presta sus servicios en el Ministerio de Defensa, Justicia Penal Militar y su Ministerio Público y, miembros de las corporaciones públicas. Ratifica reconocimientos pensionales de Empresas en concordato preventivo u obligatorio y, en pro de los derechos adquiridos leyes y convenciones colectivas del sector público y privado.

La ley 100, estableció en su artículo 33, los siguientes requisitos para ser beneficiario a una pensión de vejez con Régimen de Prima Media:

Tabla 3. Requisitos para ser beneficiarios de una pensión de vejez.

\begin{tabular}{lll}
\hline \multirow{2}{*}{ Ley 100 de 1993} & Mujer & Hombre \\
\cline { 2 - 3 } & 55 años $(+) 1000$ semanas & 60 años $(+) 1000$ semanas \\
\hline
\end{tabular}

Fuente: Elaboración propia a partir de la normativa.

Con la finalidad de respetar los derechos adquiridos, se estableció un régimen de transición en el artículo 36, que permite a un grupo representativo de personas ser beneficiario de su pensión de vejez bajo normas anteriores, tales como: Decreto 758 de 1990, Ley 33 de 1985 y Ley 71 de 1988, como una forma de garantizar el derecho que estas personas tenían a pensionarse de acuerdo a normatividad anterior; el beneficio consistía en respetar la edad, el tiempo de servicios o semanas de cotización y el monto de la pensión establecidos en las normas anteriores. Los regímenes de transición en materia de seguridad social son beneficios taxativos en el ordenamiento jurídico, que se dan en la transición de una(s) ley(es) a otra(s), y consiste en conceder derechos pensionales para acceder a una pensión con el lleno de los requisitos estipulados en leyes anteriores, omitiendo leyes actuales que resultan ser menos favorables. En el caso concreto, el régimen de transición consagrado en el Artículo 36 de la Ley 100 de 1993, da la posibilidad de pensionarse con leyes anteriores más favorables siempre y cuando se cumpla con los requisitos estipulados allí, es decir, 35 o más años de edad si son mujeres o 40 o más años de edad si son hombres, o 750 semanas cotizadas o 15 años de servicio, verificados al 01 de abril de 1994, para particulares y servidores públicos de nivel nacional y departamental, y 30 de junio de 1995, para servidores públicos territoriales, entrada en vigencia de la Ley (Congreso de la República de Colombia, 1993).

En principio las personas que cumplieran con dados requisitos tendrán derecho a pensionarse según el marco normativo anterior a la Ley 100 de 1993 y que a continuación se describen: 
Tabla 4. Marco normativo antes de la ley 100 de 1993.

\begin{tabular}{|c|c|c|}
\hline Normas & $\begin{array}{l}\text { Requisitos para ser beneficiarios de una pensión } \\
\text { de vejez }\end{array}$ & Beneficios que ofrece \\
\hline $\begin{array}{l}\text { Decreto } 758 \text { de } \\
1990, \text { artículo } \\
12\end{array}$ & $\begin{array}{l}\text { Personas que reúnan: a) Sesenta (60) o más años } \\
\text { si se es varón o cincuenta y cinco (55) o más } \\
\text { años, si se es mujer y, b) Un mínimo de quinientas } \\
\text { (500) semanas de cotización durante los últimos } \\
\text { veinte (20) años anteriores al cumplimiento de las } \\
\text { edades mínimas, o haber acreditado un número } \\
\text { de un mil (1.000) semanas de cotización, en } \\
\text { cualquier tiempo. }\end{array}$ & $\begin{array}{l}\text { Exige menos semanas } \\
\text { y concede una tasa de } \\
\text { reemplazo hasta del } 90 \% \text {. }\end{array}$ \\
\hline $\begin{array}{l}\text { Ley } 71 \text { de } 1988, \\
\text { artículo } 7\end{array}$ & $\begin{array}{l}\text { Los empleados oficiales y trabajadores que } \\
\text { acrediten veinte (20) años de aportes sufragados } \\
\text { en cualquier tiempo y acumulados en una o varias } \\
\text { de las entidades de previsión social que hagan } \\
\text { sus veces, del orden nacional, departamental, } \\
\text { municipal, intendencia, comisaria o distrital y en el } \\
\text { Instituto de los Seguros Sociales, tendrán derecho } \\
\text { a una pensión de jubilación siempre que cumplan } \\
\text { sesenta (60) años o más si es varón y cincuenta y } \\
\text { cinco (55) años o más si es mujer. }\end{array}$ & $\begin{array}{l}\text { Protege a personas } \\
\text { que trabajaron para } \\
\text { entidades públicas y } \\
\text { privadas, ofreciéndoles } \\
\text { además un ingreso base } \\
\text { de liquidación como si } \\
\text { hubiesen sido servidores } \\
\text { públicos. }\end{array}$ \\
\hline $\begin{array}{l}\text { Ley } 33 \text { de } 1985, \\
\text { artículo } 1\end{array}$ & $\begin{array}{l}\text { El empleado oficial que sirva o haya servido } \\
\text { veinte (20) años continuos o discontinuos y llegue } \\
\text { a la edad de cincuenta y cinco (55) años tendrá } \\
\text { derecho a que por la respectiva Caja de Previsión } \\
\text { se le pague una pensión mensual vitalicia de } \\
\text { jubilación. }\end{array}$ & $\begin{array}{l}\text { Diseñada solo para los } \\
\text { servidores públicos, } \\
\text { asignando la misma } \\
\text { edad a las mujeres y } \\
\text { a los hombres, para } \\
\text { ser beneficiarios de } \\
\text { una pensión de vejez } \\
\text { y un ingreso base de } \\
\text { liquidación más favorable. }\end{array}$ \\
\hline
\end{tabular}

Fuente: elaboración propia a partir de la normatividad.

A partir de la Ley 100 se establecieron dos regímenes pensionales, el Régimen de Prima Media con Prestación Definida (RPM) y el Régimen de Ahorro Individual con Solidaridad (RAIS)(Ley 100, 1993, p. 100). El régimen de prima media con prestación definida es de carácter público y se basa en el principio de la solidaridad, los aportes de los cotizantes son incluidos en un fondo común administrado por el Instituto de Seguros Sociales, hoy Administradora Colombiana de Pensiones -Colpensiones-; la solidez y sostenibilidad del fondo común depende del número de afiliados, de la edad de los afiliados, del valor y frecuencia de los aportes y de sus costos de administración; la pensión por vejez se otorga a partir del cumplimiento de una edad y un número mínimo de semanas de cotización. Las prestaciones económicas pensionales en este caso son pagadas con las cotizaciones que realizan los afiliados a Colpensiones y con recursos del Presupuesto Nacional.

Desde otro punto de vista, en la Ley 100 de 1993 se prescribe varias modalidades para ser beneficiarios a una pensión de vejez en Colombia, la cuales son: 
Figura 1. Modalidades de pensión de vejez.

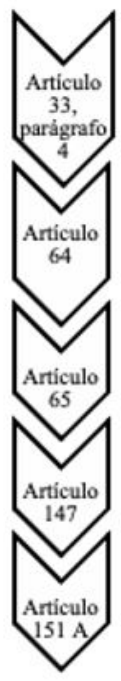

- Pensión de vejez por defíciencia y la pensión especial de madre o padre con hijo en condición de invalidez

-Pensión anticipada de vejez

- Garantía de pensión mínima

- Garantía de pensión mínima para desmovilizados

- Pensión familiar

Fuente: elaboración propia a partir de la normatividad.

Por otro lado, es importante indicar que el 29 de enero de 2003, entró a regir la Ley 797 de 2003 (Congreso de la República de Colombia, 2003), la cual, en materia de pensión de vejez, cambió los requisitos establecidos en el artículo 33 y 36 de la Ley de 100 de 1993, para poder ser beneficiario de la misma y estableció lo siguiente:

Tabla 5. Requisitos para ser beneficiarios de una pensión de vejez.

\begin{tabular}{lll}
\hline Criterio de modificación legislativo & 2003 - 2013 & A partir de 2014 \\
\hline Incremento de la edad para las mujeres & 55 & 57 \\
\hline Incremento de la edad para los hombres & 60 & 62 \\
\hline $\begin{array}{l}\text { Incremento de las semanas necesarias para } \\
\text { ser beneficiarios de una pensión de vejez }\end{array}$ & $1000-1250$ & $\begin{array}{l}1275- \\
\text { (1300 para el 2015) }\end{array}$ \\
\hline Monto & Fórmula: (65\%) & \\
\hline IBL & últimos 10 años cotizados o toda la vida \\
\hline
\end{tabular}

Fuente: elaboración propia a partir de la normatividad.

Asimismo, las prebendas normativas se fueron reduciendo y en el año 2005 mediante Acto Legislativo 01 (presidente de la República, 2005), publicado en el diario oficial número 45980 del 25 de julio de 2005, corregido mediante Decreto 2576 de Julio 29 de 2005 (Presidente de la República, 2005), se modifica el artículo 48 de la Constitución Política de Colombia; el cual se restringe en materia de pensión de vejez lo siguiente: 
Tabla 6. Novedades normativas del acto legislativo 1 de 2005.

\begin{tabular}{|c|c|}
\hline \multirow{3}{*}{ Prohíbe } & $\begin{array}{l}\text {-La denominada mesada 14. "Las personas cuyo derecho a la pensión se cause a } \\
\text { partir de la vigencia del presente Acto Legislativo no podrán recibir más de trece (13) } \\
\text { mesadas pensionales al año (...) se exceptúan aquellas personas que perciban una } \\
\text { pensión igual o inferior a tres (3) salarios mínimos legales mensuales vigentes, si la } \\
\text { misma se causa antes del } 31 \text { de julio de 2011". }\end{array}$ \\
\hline & $\begin{array}{l}\text { - Pactar condiciones diferentes a las del sistema pensional en pactos, convenciones } \\
\text { colectivas de trabajo, laudos o actos jurídicos. Los suscritos entre el } 29 \text { de julio de } 2005 \\
\text { y el } 31 \text { de julio de } 2010 \text {, no podrán estipularse condiciones pensionales más favorables } \\
\text { que las que se encuentren actualmente vigentes. En todo caso perderán vigencia el } 31 \\
\text { de julio de } 2010 \text {. }\end{array}$ \\
\hline & $\begin{array}{l}\text { - Pensiones inferiores al salario mínimo y pensiones superiores a } 25 \text { salarios mínimos } \\
\text { a partir del } 31 \text { de julio de } 2010, \text { con cargo a recursos públicos. } \\
\text {-Establecer regímenes especiales y exceptuados a partir del } 29 \text { de julio de } 2005 . \\
\text { Perderán vigencia a partir del } 31 \text { de julio de } 2010 \text {. "(...) sin perjuicio del aplicable a la } \\
\text { fuerza pública, al Presidente de la República". }\end{array}$ \\
\hline $\begin{array}{l}\text { Limita y } \\
\text { elimina }\end{array}$ & $\begin{array}{l}\text { Parágrafo transitorio 4." El régimen de transición establecido en la Ley } 100 \text { de } 1993 \text { y } \\
\text { demás normas que desarrollen dicho régimen, no podrá extenderse más allá del } 31 \text { de } \\
\text { julio de 2010; excepto para los trabajadores que estando en dicho régimen, además, } \\
\text { tengan cotizadas al menos } 750 \text { semanas o su equivalente en tiempo de servicios a la } \\
\text { entrada en vigor del presente Acto Legislativo, a los cuales se les mantendrá dicho } \\
\text { régimen hasta el año 2014". }\end{array}$ \\
\hline Crea & Los Beneficios Económicos Periódicos (BEPS) \\
\hline
\end{tabular}

Fuente: elaboración propia a partir de la normatividad.

De acuerdo con el portal de datos abiertos del Gobierno Nacional, a diciembre de 2019 Colpensiones contaba con 6.870.364 afiliados; y a marzo 16 de 2020, con 1.380.977 pensionados (Ministerio de Tecnologías de la Información y las Comunicaciones, 2020). El número de pensionados por Colpensiones por rango salarial a marzo 16 de 2020 (Ministerio de Tecnologías de la Información y las Comunicaciones, 2020), es:

Tabla 7. Número de pensionados por Colpensiones por rango salarial.

\begin{tabular}{ccc}
\hline Rango Salarial & Número de pensionados & Valor mensual mesadas (millones \$) \\
\hline$<=1$ SMMLV & 720.420 & 599.485 \\
\hline$>1<=2$ SMMLV & 342.543 & 405.561 \\
\hline$>2<=3$ SMMLV & 138.047 & 279.608 \\
\hline$>3<=5$ SMMLV & 102.371 & 324.563 \\
\hline$>5<=10$ SMMLV & 60.880 & 343.542 \\
\hline$>10<=20$ SMMLV & 16.422 & 177.271 \\
\hline$>20$ SMMLV & 294 & 5.554 \\
\hline
\end{tabular}

Fuente: Ministerio de Tecnologías de la Información y las Comunicaciones, 2020.

Con lo anterior se evidencia que la Administradora Colombiana de Pensiones -Colpensiones tiene el $20 \%$ de sus pensionados con mesadas superiores a tres (3) salarios mínimos legales mensuales vigentes y; un $25 \%$ de sus pensionados con mesadas entre más de uno (1) y tres (3) salarios mínimo-legales mensuales vigentes. 
Por otra parte, el Régimen de Ahorro Individual con Solidaridad (RAIS) es gestionado por las Administradoras de Fondos de Pensiones (AFP), en la actualidad se encuentra: Protección S.A., Porvenir S.A., Colfondos S.A. y Old Mutual S.A.; en este régimen el aporte de los afiliados se deposita en una cuenta de ahorro individual hasta crear un capital suficiente para financiar la prestación por vejez; si la persona no reúne el capital suficiente puede aspirar a una pensión del salario mínimo siempre y cuando tenga 1150 semanas cotizadas, la edad pensional (57 años mujeres y 62 años hombres); el capital ahorrado está expuesto a las condiciones o variables económicas y los rendimientos por la inversión que realice la Administradora.

En el RAIS existen varias modalidades de pensión, las cuales son la forma mediante la cual el pensionado o beneficiario puede escoger el pago de su pensión de vejez, en el artículo 79 de la Ley 100 de 1993 se establece tres modalidades: renta vitalicia inmediata, retiro programado, retiro programado con renta vitalicia diferida y las demás que autorice la Superintendencia financiera de Colombia (SFC); en consecuencia la Superintendencia financiera mediante Circular externa 13 de 2012, creó 4 nuevas modalidades: renta temporal variable con renta vitalicia diferida, renta temporal variable con renta vitalicia inmediata, retiro programado sin negociación del bono pensional y renta temporal cierta con renta vitalicia de diferimiento cierto (Superintendencia Financiera de Colombia, 2012).

El artículo 80 de la Ley 100 de 1993, establece lo que es la renta vitalicia inmediata, señalándole como: "(...) la modalidad de pensión mediante la cual el afiliado o beneficiario contrata directa e irrevocablemente con la aseguradora de su elección, el pago de una renta mensual hasta su fallecimiento y el pago de pensiones de sobrevivientes en favor de sus beneficiarios por el tiempo a que ellos tengan derecho. Dichas rentas y pensiones deben ser uniformes en términos de poder adquisitivo constante y no pueden ser contratadas por valores inferiores a la pensión mínima vigente del momento."

El artículo 81 de la misma ley señala que es la modalidad de retiro programado exponiendo que es cuando: "(...) el afiliado o los beneficiarios, obtienen su pensión de la sociedad administradora, con cargo a su cuenta individual de ahorro pensional y al bono pensional a que hubiera lugar. Para estos efectos, se calcula cada año una anualidad en unidades de valor constante, igual al resultado de dividir el saldo de su cuenta de ahorro y bono pensional, por el capital necesario para financiar una unidad de renta vitalicia para el afiliado y sus beneficiarios. La pensión mensual corresponderá a la doceava parte de dicha anualidad." (Ley 100, 1993, art. 81).

Asimismo, el artículo 82 de la Ley 100 de 1993 establece el Retiro Programado con Renta Vitalicia Diferida, como: “(...) la modalidad de pensión por la cual un afiliado contrata con la aseguradora de su elección, una renta vitalicia con el fin de recibir pagos mensuales a partir de una fecha determinada, reteniendo en su cuenta individual de ahorro pensional, los fondos suficientes para obtener de la administradora un retiro programado, durante el período que medie entre la fecha en que ejerce la opción por esta modalidad y la fecha en que la renta vitalicia diferida comience a ser pagada por la aseguradora. La renta vitalicia diferida contratada tampoco podrá en este caso, ser inferior a la pensión mínima de vejez vigente."

Según la Superintendencia Financiera de Colombia, a febrero 29 de 2020 el RAIS tenía 16.617.248 afiliados y 187.552 pensionados (Superintendencia Financiera de Colombia, 2020). 
Tabla 8. Tabla Afiliados 2020.

\begin{tabular}{ll}
\hline & Afiliados - año 2020 \\
\hline Fondo moderado & Febrero \\
\hline Protección & 746.237 \\
Porvenir & 1.360 .590 \\
Skandia & 29.478 \\
Colfondos & 338.948 \\
Skandia alternativo & 268 \\
Total & $\mathbf{2 . 4 7 5 . 5 2 1}$ \\
\hline Fondo conservador & Febrero \\
\hline Protección & 320.098 \\
Porvenir & 587.672 \\
Skandia & 11.894 \\
Colfondos & 163.893 \\
Total & $\mathbf{1 . 0 8 3 . 5 5 7}$ \\
\hline Fondo de mayor riesgo & Febrero \\
\hline Protección & 3.824 .612 \\
Porvenir & 7.718 .086 \\
Skandia & 81.259 \\
Colfondos & 1.434 .213 \\
\hline Total & $\mathbf{1 3 . 0 5 8 . 1 7 0}$ \\
\hline & $\mathbf{1 6 . 6 1 7 . 2 4 8}$ \\
\hline
\end{tabular}

Fuente: Elaboración propia con base a los datos suministrados por la Superintendencia Financiera de Colombia, 2020.

Sobre la rentabilidad, según datos de la Superintendencia Financiera que la rentabilidad de los fondos de pensiones hasta febrero 29 de 2020 era: 
Tabla 9. Rentabilidad de Fondos de Pensión.

\begin{tabular}{|c|c|c|c|c|c|c|c|c|}
\hline \multirow{4}{*}{ Fondo } & \multicolumn{8}{|c|}{$\begin{array}{l}\text { Fondo de pensiones obligatorias* } \\
\text { Hasta } 29 / 02 / 2020\end{array}$} \\
\hline & \multirow{2}{*}{\multicolumn{2}{|c|}{$\begin{array}{c}\begin{array}{c}\text { Fondo } \\
\text { conservador }\end{array} \\
\text { Últimos } 36 \text { meses }\end{array}$}} & \multirow{2}{*}{\multicolumn{2}{|c|}{$\begin{array}{l}\text { Fondo moderado } \\
\text { Últimos } 48 \text { meses }\end{array}$}} & \multirow{2}{*}{\multicolumn{2}{|c|}{$\begin{array}{c}\begin{array}{c}\text { Fondo mayor } \\
\text { riesgo }\end{array} \\
\text { Últimos } 60 \text { meses }\end{array}$}} & \multirow{2}{*}{\multicolumn{2}{|c|}{$\begin{array}{c}\begin{array}{c}\text { Fondo retiro } \\
\text { programado }\end{array} \\
\text { Últimos } 48 \text { meses }\end{array}$}} \\
\hline & & & & & & & & \\
\hline & Nominal & Real & Nominal & Real & Nominal & Real & Nominal & Real \\
\hline Protección & $8,17 \%$ & $4,65 \%$ & $9,51 \%$ & $5,66 \%$ & $7,54 \%$ & $2,85 \%$ & $10,36 \%$ & $6,31 \%$ \\
\hline Porvenir & $8,32 \%$ & $4,80 \%$ & $10,24 \%$ & $6,37 \%$ & $7,63 \%$ & $2,94 \%$ & $10,74 \%$ & $6,67 \%$ \\
\hline Skandia & $8,67 \%$ & $5,13 \%$ & $10,73 \%$ & $6,84 \%$ & $8,89 \%$ & $4,15 \%$ & $10,51 \%$ & $6,44 \%$ \\
\hline Colfondos & $8,19 \%$ & $4,67 \%$ & $9,69 \%$ & $5,83 \%$ & $9,63 \%$ & $4,85 \%$ & $10,59 \%$ & $6,52 \%$ \\
\hline Promedio & $8,27 \%$ & $4,75 \%$ & $9,93 \%$ & $5,89 \%$ & $7,82 \%$ & $3,12 \%$ & $10,54 \%$ & $6,48 \%$ \\
\hline $\begin{array}{l}\text { Rentabilidad } \\
\text { mínima }\end{array}$ & $5,90 \%$ & & $6,38 \%$ & & $4,11 \%$ & & & \\
\hline \multicolumn{9}{|c|}{$\begin{array}{l}\text { Estas rentabilidades no son necesariamente } \\
\text { indicativos de futuros resultados }\end{array}$} \\
\hline \multicolumn{9}{|c|}{ Fuente: Informes presentados por las AFP. } \\
\hline \multicolumn{9}{|c|}{$\begin{array}{l}\text { * El decreto } 2949 \text { de } 2010 \text { por el cual se modifica el Decreto } 2550 \text { de } 2010 \text {, en su artículo 2.6.5.1.4 } \\
\text { establece el período de cálculo de la rentabilidad mínima para los tipos de fondos de pensiones } \\
\text { obligatorias. } \\
\text { ** Para el Fondo de Retiro Programado el Decreto } 059 \text { de } 2018 \text { estableció un período de } \\
\text { transición, y modificó la metodología, el periodo de cálculo, y la verificación de la rentabilidad } \\
\text { mínima obligatoria, para la cual se realizará una primera revisión a partir del } 30 \text { de junio de } 2020 \text {. }\end{array}$} \\
\hline
\end{tabular}

Fuente: Superintendencia Financiera de Colombia, 2020.

No obstante, cabe mencionar que la información sobre rendimientos que es divulgada por las Administradoras de Fondos de Pensiones mediante la Superintendencia Financiera de Colombia, se hace en términos nominales, sin tener en cuenta los cargos por comisión, seguros y tampoco los ajustes por inflación, en adición es suavizada en periodos de 60 meses para el fondo de mayor riesgo, 48 meses para el fondo moderado y 36 meses para el fondo conservador, de acuerdo con categorización de fondos por nivel de riesgo, desconociéndose la rentabilidad real; siendo necesario conocer la rentabilidad no en término nominales sino reales, en la medida que "son los retornos reales los que permiten hacer comparaciones sobre el desempeño financiero de los fondos privados a nivel internacional y desde la perspectiva del afiliado permiten conocer cuál es el incremento en la capacidad adquisitiva de todos los recursos que ha dispuesto como ahorro para pensión."(Salazar, 2020)

La rentabilidad en los últimos 20 años según el "documento técnico comparativo de metodologías de cálculo de la rentabilidad nominal y real para las administradoras de fondos de pensiones en Colombia" emitido por la Superintendencia Financiera (Superintendencia Financiera de Colombia, 2019), ha sido: 
Tabla 10. Rentabilidad Fondo Moderado en los últimos 20 años.

\begin{tabular}{lcccccc}
\hline \multirow{2}{*}{$\begin{array}{c}\text { Fondo } \\
\text { moderado }\end{array}$} & \multicolumn{2}{c}{$\begin{array}{c}\text { Valor unidad -NAV } \\
\text { Hasta } \mathbf{3 0 / 0 6 / 2 0 1 9}\end{array}$} & $\begin{array}{c}\text { Flujo de caja } \\
\text { Hasta } \mathbf{3 0 / 0 6 / 2 0 1 9}\end{array}$ & \multicolumn{2}{c}{ TIR Hasta 30/06/2019 } \\
\cline { 2 - 7 } & Nominal & Real & Nominal & Real & Nominal & Real \\
\hline Protección & $13.13 \%$ & $7.76 \%$ & $10.75 \%$ & $6.02 \%$ & $10.75 \%$ & $5.50 \%$ \\
\hline Porvenir & $12.20 \%$ & $6.87 \%$ & $10.46 \%$ & $5.68 \%$ & 10.46 & $5.22 \%$ \\
\hline OLD M5utual & $12.95 \%$ & $7.59 \%$ & $11.26 \%$ & $6.61 \%$ & $11.26 \%$ & $5.98 \%$ \\
\hline Colfondos & $12.27 \%$ & $6.94 \%$ & $11.26 \%$ & $6.31 \%$ & $11.16 \%$ & $5.88 \%$ \\
\hline Sistema & $\mathbf{1 2 . 5 2 \%}$ & $\mathbf{7 . 1 8 \%}$ & $\mathbf{1 0 . 7 3 \%}$ & $\mathbf{5 . 9 6 \%}$ & $\mathbf{1 0 . 7 3 \%}$ & $\mathbf{5 . 4 6 \%}$ \\
\hline Período de cálculo comprendido entre 30 de junio de 1999 al 30 de junio de 2019 &
\end{tabular}

Fuente: Superintendencia Financiera de Colombia, 2019

Sobre el asunto, Salazar realiza una comparación de los rendimientos suministrados por las Administradoras de Fondos de pensiones en Colombia desde el inicio de su operación, y los traduce en rentabilidad real; para ello pone el ejemplo de un afiliado al RAIS, entre los períodos: 1995 - 2016, concluyendo que "la rentabilidad real acumulada efectiva anual que se ha generado por el sistema (fondo moderado que concentra el $83 \%$ de los fondos de pensión) es de 0,48\%. Significa esto que, una persona que inició sus cotizaciones en 1995 y ha permanecido realizando aportes hasta 2016, en términos reales, con la rentabilidad generada apenas ha logrado cubrir los costos asumidos y brindar algún tipo de protección contra la inflación, pero en términos reales los recursos sacrificados en consumo y destinados a su ahorro pensional no han crecido." (Salazar, 2020),

A modo de conclusión, con base a los datos anteriores referentes al número de afiliados y pensionados en ambos regímenes, que las AFP tienen más del doble de afiliados, 16.617.248, que Colpensiones, 6.870.364; que Colpensiones tiene más pensionados, 1.380.977, que las AFP, 187.552. Luego, en principio, las AFP tienen ingresos mensuales superiores que Colpensiones, y este último un gasto superior por pago en pensiones.

En relación a las AFP, no se evidencia una utilidad real para sus afiliados y menos para los que llegan a ser beneficiarios de una pensión de vejez, en últimas es incompatible los cálculos contables y financieros con el derecho fundamental de pensión de vejez y protección integral a la vejez; a la luz de la Constitución Política de Colombia de 1991 y el derecho internacional de la seguridad social, la esencia del Régimen de Ahorro individual con solidaridad pone en duda la competencia de las administradoras para satisfacer las actuales pretensiones pensionales que se presentan en Colombia, dirigidas al ideal de protección integral a la vejez.

Por lo tanto, se debe abordar el análisis con base a que las personas mayores que contribuyeron durante un tiempo determinado para ser beneficiarios de una pensión de vejez, son afectados por los diferentes cambios normativos que incrementan requisitos para que sean beneficiarios de dada prestación económica en adición tienen reglas de juego en materia pensional que no son acordes con realidades históricas, sociales y económicas; luego, independientemente de que hayan contribuido o no, son personas, que por su condición de debilidad manifiesta son sujetos de especial protección constitucional y necesitan que sus derechos humanos tales como la dignidad humana, salud, vida y mínimo vital se encuentren salvaguardados. 
En Colombia, las personas mayores son sujetos de especial protección, personas que, debido a su condición particular, a saber, físicas, económicas, psicológicas y sociales, merecen un amparo reforzado en aras de lograr una igualdad real y efectiva, no obstante, la normatividad en pro de proteger sus derechos ha estado enmarcada en desarrollos jurídicos en materia de pensión de vejez, dejando a un lado todo aquel que no pudo estar dentro del mercado laboral y contribuir al sistema pensional; queda en evidencia que la aplicación normatividad en materia de pensión de vejez, no satisface la pretensión de protección integral a la vejez.

Lo anterior, tiene su fundamento en la constante tasa de desempleo que se ha tenido, los indicadores de desempleo publicados por el Departamento Administrativo Nacional de Estadística (DANE) en los siguientes términos:

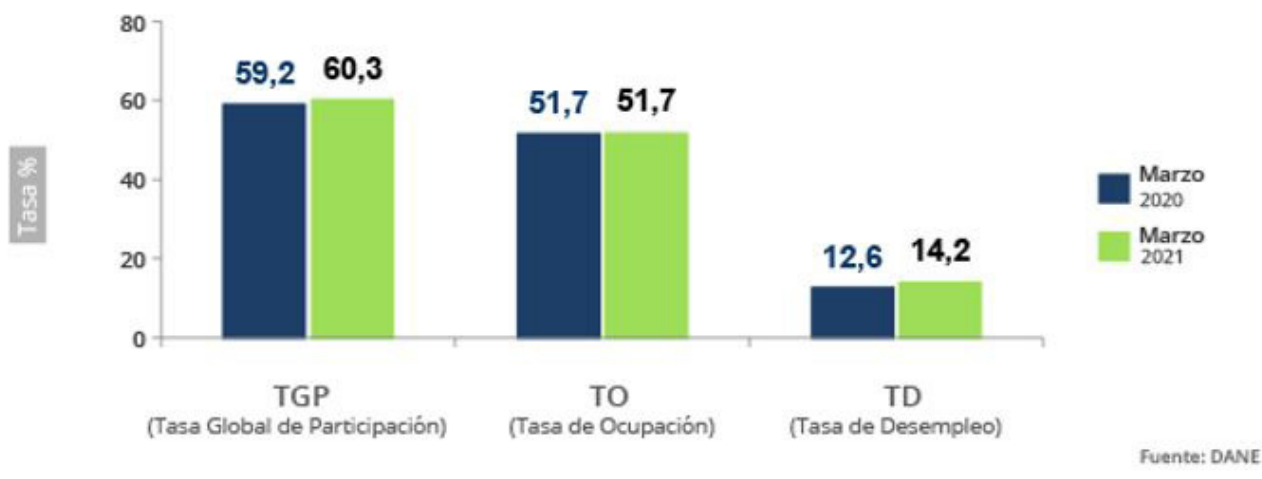

Figura 2. Tasa de desempleo en Colombia.

Fuente: Dane 2021 https://www.dane.gov.co/index.php/estadisticas-por-tema/mercado-laboral/empleo-y-desempleo

Esta perspectiva que se seguirá dando en los años siguientes, ya que la situación económica del país constituida por el déficit fiscal y la deuda externa impiden grandes avances en esta materia, a lo que se suman otro tipo de situaciones como las crisis económicas de carácter internacional y la volatilidad del mercado bursátil mundial por la pandemia COVID-19.

De acuerdo con Uribe, dada la importancia de los mercados laborales para el bienestar, el empleo es la fuente principal de acceso al consumo para la gran mayoría de la población, el análisis económico se concentra en explicar su comportamiento y en proponer políticas para que funcionen óptimamente. El empleo que se tiene, o no, representa no solo una fuente de ingresos, sino que también ofrece posibilidades de desarrollo de nuestras capacidades y posibilita el acceso a una serie de servicios que hacen parte fundamental del lugar que se ocupa en la sociedad: seguridad social, educación, recreación, etc. La concepción teórica que inspira la obra de Uribe parte de que el mercado laboral es un mercado especial porque la demanda laboral es una demanda derivada, es decir, que lo que ocurre en el mercado laboral depende de lo que ocurre en otros mercados como el de bienes, o el del dinero. De tal suerte que, para proponer soluciones a los problemas laborales, no basta con flexibilizar el mercado laboral, se deben crear las condiciones para generar crecimiento y, por lo tanto, demanda de empleo de buena calidad. (2006). 
Sobre la protección a la persona mayor, necesario redireccionar el enfoque jurídico en materia de protección a la vejez, en la medida que no se debe limitar a una prestación económica producto de contribuciones realizadas durante una vida y dentro de un mercado laboral selecto, sino que la vejez, debe ser vista como un periodo de la vida que debe ser recompensado con actuaciones positivas por parte del Estado, la sociedad y la familia, en pro de contrarrestar los efectos negativos que puede conllevar la misma, ello con base a que, si hablamos de trabajar, dado verbo no se debe entender bajo la premisa de ocupaciones laborales clásicas reconocidas formalmente, sino que debemos ir más allá, y entender que hay una diversidad de trabajo diario que todo ser humano debe realizar en su vida cotidiana, trabajo que una persona mayor, ha desarrollado durante más de 60 años, trabajo que de manera formal o informal ha contribuido a construir sociedad.

Desde esta mirada, la figura de la pensión de vejez puede ser excluyente, protege económica y socialmente a una parte de las personas mayores, dejando otra parte desprotegida y que debe ser abordada desde la teoría de la protección integral a la vejez; dentro del ordenamiento jurídico colombiano se encuentra una política pública de envejecimiento humano y vejez que busca garantizar una protección integral de las personas mayores, con base a ella se ha desarrollado normas en pro de los derechos humanos de todos las personas mayores, normas que obligan a movilizar acciones a nivel institucional que haga coherente la planificación del sistema con la ejecución del mismo.

A continuación, se amplia el concepto de protección integral a la vejez y se revisa en el ámbito nacional normativo sobre este tema:

\section{Protección integral a la vejez}

La palabra vejez se forma de la raíz de la palabra latina vetusto-a (vetustus), que significa antiguo y del sufijo -ez que indica cualidad. La vejez hace referencia a la senectud o edad senil, la palabra senectud tiene origen en el sustantivo latino senectus que significa edad y a su vez del verbo senescere que significa envejecer, la senectud es la última etapa de la vida de un ser humano que se caracteriza por el envejecimiento biológico. (Corominas, 2005)

El término persona mayor nace del latín adultus, que significa crecer o madurar, mientras que mayor nace del latín maior, cuyo significado hace referencia a grande en edad. El término hace alusión a los últimos años de vida de un ser humano. (Corominas, 2005).

Desde la edad antigua, se creó dos versiones de la vejez, el primero expuesto por Platón en su escrito, la Republica, en donde elogia a la vejez y la cataloga como aquella etapa de la vida en la que las personas alcanzan la máxima prudencia, discreción, sagacidad y juicio (1365 AE) y; la segunda, esgrimida por Aristóteles en, la Retórica, libros II, XII, XIIIXIV, 3, donde manifiesta que la "senectud", es la cuarta y última etapa en la vida del hombre, la cual equivale a deterioro y ruina, en la medida que es una etapa de debilidades, digna de compasión social e inútil social (1355 AE). Estas dos versiones son desarrolladas por diversos autores a la hora abordar el concepto de vejez, siendo las mismas responsables de los estereotipos asignados a la vejez en la actualidad. 
Sin embargo, los seres humanos no acostumbraban, debido a las constantes guerras o enfermedades infecciosas, en la edad antigua, media o contemporánea, en su gran mayoría, a llegar a ese periodo denominado vejez; el interés en general surgió después de la Segunda Guerra Mundial, en donde la humanidad se enfrenta a una población cada vez mayor, por primera vez en la historia era habitual que los seres humanos llegaran a una edad avanzada. En consecuencia, en el año 1946, la Organización Mundial de la Salud, al entender el concepto de salud como "un estado de completo bienestar físico, psíquico y social y no solo la ausencia de enfermedad" (OMS, 1946), redefine el proceso de envejecimiento e involucra a diferentes actores sociales tales como: psicólogos, médicos, sociólogos, trabajadores sociales, juristas, filósofos, entre otros, con el fin de entender el ser y el deber ser de la vejez.

Desde ámbito internacional OMS ha indicado como reto de la población envejecida las necesidades de pensiones y protecciones sociales (OMS I Envejecimiento, 2021). Colombia no ha sido ajena a este compromiso internacional y estableció la Política de Envejecimiento Humano y Vejez 2015-2024 con una línea de trabajo referida a la protección social integral que articulada con la Ley 789 de 2003 pretender garantizar como mínimo el derecho a la salud, la pensión y al trabajo(Política Colombiana de Envejecimiento Humano y Vejez, 2015).

Sobre el derecho a la protección integral, (Correa Montoya, L., Rodríguez Parra, L., Suárez Ángel, C., \& Rúa Serna, J.) se encuentra referenciado en "el sistema jurídico colombiano, con base en los artículos 13 y 46 de la Constitución Política de 1991, [se] prevé una especial protección para las personas mayores. Efectivamente, el artículo 13 consagra el derecho a la igualdad, haciendo énfasis en la necesidad de que el Estado promueva "las condiciones para que la igualdad sea real y efectiva", por lo que deberá proteger especialmente a quienes por sus condiciones personales o sociales "se encuentren en circunstancia de debilidad manifiesta". Esta protección se complementa con la prevista en el artículo 46 Constitucional, en la medida en la que allí se responsabiliza tanto al Estado como a la sociedad y a la familia para que concurran en su garantía, brindando protección y asistencia a las personas mayores y promoviendo condiciones activas y dignas de integración en la comunidad." (2018, pág. 57)

En adición, y en concordancia con el artículo 13 y 46 superior, se ha expedido normas tales como; 
Tabla 11. Marco normativo para la protección integral a la vejez.

\begin{tabular}{|c|c|c|}
\hline Año & Norma & Propósito \\
\hline 2007 & Ley 1171 & $\begin{array}{l}\text { Se establecen beneficios para las personas adultas mayores } \\
\text { tales como descuentos en instituciones educativas, espectáculos, } \\
\text { transporte público, sitios turísticos, ingreso gratuito a bienes de } \\
\text { interés cultural, ventanillas preferenciales, asientos preferenciales } \\
\text { en transporte público y prioridad en consulta médica y atención en } \\
\text { consultorios jurídicos. }\end{array}$ \\
\hline 2008 & Ley 1251 & $\begin{array}{l}\text { Se fijan normas para la protección, promoción y defensa de los } \\
\text { derechos de las personas adultas mayores y se incluyen directrices } \\
\text { generales para la Política Nacional de Envejecimiento y Vejez. }\end{array}$ \\
\hline 2009 & La ley 1276 & $\begin{array}{l}\text { Ordena la protección de las personas adultas mayores, a través de } \\
\text { los centros vida o centros día, como instituciones que contribuyen } \\
\text { a brindarles una atención integral a sus necesidades y mejorar su } \\
\text { calidad de vida }\end{array}$ \\
\hline 2009 & La Ley 1315 & $\begin{array}{l}\text { Determina las condiciones mínimas para garantizar la atención } \\
\text { y prestación de servicios integrales con calidad a las personas } \\
\text { adultas mayores en instituciones de hospedaje, cuidado, bienestar y } \\
\text { asistencia social (centros de protección, centros día e instituciones } \\
\text { de atención). }\end{array}$ \\
\hline
\end{tabular}

Fuente: elaboración propia a partir de normatividad.

Las normas sin una debida ejecución de estas pueden ser insuficientes para la protección integral a la vejez. Autores como Cardona, D., Estrada, A., \& Agudelo, H hacen referencia al envejecimiento refiriendo que a medida que aumentan la edad, la calidad de vida está determinada por la capacidad para mantener la autonomía, - sea, la capacidad percibida de controlar, afrontar y tomar decisiones personales acerca de cómo vivir al día de acuerdo con las normas y preferencias propias, y la independencia, es decir, la capacidad de desempeñar las funciones relacionadas con la vida diaria, en otras palabras, capacidad de vivir recibiendo poca o ninguna ayuda de los demás (2006, pág.207); tornándose necesario la implementación de normas que garanticen un ingreso básico a las personas mayores con el fin de propender su libre desarrollo de la personalidad y en consecuencia su calidad de vida.

Además de sus limitaciones biológicas la normatividad colombiana impone barreras a las personas mayores cada vez más gravosas para poder tener un sustento económico y un espacio en la sociedad con más posibilidades de ser digno; en la actualidad no se cuenta con instrumentos eficientes y eficaces en pro de los derechos de las personas mayores, desconociendo una realidad, ¡Todos están envejecimiento! Organismos como la OIT han planteado que el principal problema en Colombia es la baja cobertura a la vejez, debido al amplio porcentaje poblacional que comprenden las personas mayores y los bajos niveles de acceso a recursos obtenidos a través de una pensión o algún subsidio del estado, situación que es la puerta de entrada a otras problemáticas de tipo social e institucional; la desigualdad derivada de la falta de ingresos genera inequidad. (OIT, 2002)

Desde el punto de vista social, hay una realidad, la cual es el envejecimiento humano y el crecimiento exponencial del mismo. Cada día son más los individuos que ingresan al círculo de la vejez, seres humanos que se encuentran en estado de debilidad y que son acreedores de derechos que al mismo tiempo son vulnerados por el marco normativo establecido para proteger a la vejez; la vulneración de dados derechos por 
parte de la normatividad colombiana tiene como consecuencia, una población con más probabilidades de pobreza, analfabetismo y enfermedad. Antes de la COVID 19, la normatividad en materia pensional y la establecida para proteger a la persona mayor, no satisfacen las pretensiones incoadas con base a la constante vulneración de sus derechos fundamentales; en consecuencia, el envejecimiento poblacional y el aumento de la población considerada persona mayor, la alta incidencia en la pobreza, la inequidad social, la baja cobertura del sistema de la seguridad social integral y la tendencia hacia el deterioro en las redes de apoyo familiar, se le adhiere la actual contingencia, que trae consigo, efectos primarios del virus, en la medida que las personas mayores son más vulnerables a tener consecuencias catastróficas si se llegaren a contagiar y, secundarios, como pérdidas, familiares, sociales, económicas e inestabilidad emocional.

En el Boletín de Prensa No 434 de 2020, emitido por el Ministerio de Salud, señalo el Presidente de la República, Iván Duque Márquez, indico que las personas mayores de 70 años representan el $49 \%$ de las muertes ocasionadas por las Covid, debido a que este grupo etario es el más vulnerable al virus, y si una persona de esta edad se contagia, la posibilidad de morir es del 30\%, además, si es mayor de 80 años puede superar el 40\%. (Minsalud, 2020)

Sin embargo, ante la llegada de la COVID - 19, el Gobierno de Colombia ha adoptado medidas para contrarrestar el doble daño social, económico y sanitario que enfrenta la persona mayor.

\section{Medidas de protección a la vejez en tiempos de la COVID -19}

La Organización Mundial de la Salud define el concepto de Pandemia como: “(...) la propagación mundial de una nueva enfermedad. Se produce una pandemia de gripe cuando surge un nuevo virus gripal que se propaga por el mundo y la mayoría de las personas no tienen inmunidad contra él" (Organización Mundial de la salud, 2020).

El 7 de enero de 2020 la Organización Mundial de la Salud identificó el Coronavirus COVID-19 y declaró este brote como emergencia de salud pública de importancia internacional; el 6 de marzo de 2020 el Ministerio de Salud y de la Protección Social de Colombia dio a conocer el primer caso de brote de enfermedad producido por el Coronavirus COVID-19 en el territorio nacional; el 11 de marzo de 2020 el director general de la Organización Mundial de la Salud (OMS), Tedros Adhanom Ghebreyesus, declaró el brote de COVID-19 <<pandemia>> (Organización Mundial de la Salud, 2020); en consecuencia el Gobierno Nacional de Colombia declaró el Estado Emergencia Económica, Social y Ecológica en todo el territorio nacional, mediante el Decreto 417 del 17 marzo de 2020 , con el fin de "conjurar la grave calamidad pública que afecta al país por causa del Coronavirus COVID-19". (Presidente de la República, 2020).

Con base a lo anterior el Presidente de la República de Colombia haciendo uso de sus facultades extraordinarias expide los siguientes Decretos Legislativos con el fin de proteger a la vejez en Colombia: 
Tabla 12. Algunas normas relacionadas protección integral en la vejez a partir del 2020.

\begin{tabular}{|c|c|c|c|}
\hline $\begin{array}{c}N^{\circ} \text { del Decreto } \\
\text { Legislativo }\end{array}$ & $\begin{array}{c}\text { Fecha de } \\
\text { expedición }\end{array}$ & Objeto & Medida de protección \\
\hline $\begin{array}{l}458 \\
\text { (Declarado } \\
\text { exequible por } \\
\text { la Sentencia C } \\
150 \text { del 2020) }\end{array}$ & $\begin{array}{c}\text { marzo } 22 \\
\text { del } 2020\end{array}$ & $\begin{array}{l}\text { Tomar medidas para los hogares } \\
\text { en condición de pobreza en todo } \\
\text { el territorio Nacional, dentro del } \\
\text { Estado de Emergencia Económica, } \\
\text { Social y Ecológica. }\end{array}$ & $\begin{array}{l}\text { Transferencia monetaria, } \\
\text { no condicionada, adicional } \\
\text { y extraordinaria a los } \\
\text { beneficiarios del programa } \\
\text { Familias en Acción, Protección } \\
\text { Social al Adulto Mayor y } \\
\text { Jóvenes en Acción. }\end{array}$ \\
\hline $\begin{array}{l}486 \\
\text { (Declarado } \\
\text { exequible por } \\
\text { la Sentencia C } \\
218 \text { del 2020) }\end{array}$ & $\begin{array}{l}\text { marzo } 27 \\
\text { del } 2020\end{array}$ & $\begin{array}{l}\text { Por el cual se crea un incentivo } \\
\text { económico para los trabajadores } \\
\text { y productores del campo y se } \\
\text { adoptan otras medidas para } \\
\text { garantizar el permanente } \\
\text { funcionamiento del sistema de } \\
\text { abastecimiento de productos } \\
\text { agropecuarios y seguridad } \\
\text { alimentaria en todo el territorio } \\
\text { nacional, dentro del Estado de } \\
\text { Emergencia Económica, Social y } \\
\text { Ecológica. }\end{array}$ & $\begin{array}{l}\text { El Ministerio de Agricultura y } \\
\text { Desarrollo Rural podrá generar } \\
\text { un incentivo económico a } \\
\text { aquellos trabajadores del } \\
\text { campo mayores } 70 \text { años que } \\
\text { tengan aislamiento obligatorio } \\
\text { en marco las causas que } \\
\text { originaron la Emergencia. }\end{array}$ \\
\hline $\begin{array}{l}518 \\
\text { (Declarado } \\
\text { exequible por } \\
\text { la Sentencia C } \\
174 \text { del 2020) }\end{array}$ & $\begin{array}{c}\text { abril } 4 \text { del } \\
2020\end{array}$ & $\begin{array}{l}\text { Por el cual se crea el Programa } \\
\text { Ingreso Solidario para atender } \\
\text { las necesidades de los hogares } \\
\text { en situación de pobreza y } \\
\text { vulnerabilidad en todo el territorio } \\
\text { nacional. }\end{array}$ & $\begin{array}{l}\text { Créase el Programa Ingreso } \\
\text { Solidario, bajo la administración } \\
\text { del Ministerio de Hacienda } \\
\text { y Crédito Público, mediante } \\
\text { el cual se entregarán } \\
\text { transferencias monetarias } \\
\text { no condicionadas con cargo } \\
\text { a los recursos del Fondo de } \\
\text { Mitigación de Emergencia en } \\
\text { favor de las personas y hogares } \\
\text { en situación de pobreza y } \\
\text { vulnerabilidad, que no sean } \\
\text { beneficiarios de los programas } \\
\text { Familias en Acción, Protección } \\
\text { Social al Adulto Mayor. }\end{array}$ \\
\hline $\begin{array}{l}553 \\
\text { (Declarado } \\
\text { exequible por } \\
\text { la Sentencia C } \\
195 \text { del 2020) }\end{array}$ & $\begin{array}{l}\text { abril } 15 \\
\text { del } 2020\end{array}$ & Ayudas económicas (Adulto Mayor). & $\begin{array}{l}\text { Con recursos del FOME se } \\
\text { podrán financiar } 3 \text { giros } \\
\text { mensuales de } \$ 80.000 \text { para } \\
\text { lista de priorización del } \\
\text { programa Colombia Mayor. Los } \\
\text { adultos mayores beneficiarios } \\
\text { de la compensación del IVA solo } \\
\text { recibirán } 2 \text { pagos de } \$ 80.000 \text {. }\end{array}$ \\
\hline $\begin{array}{l}\text { Decreto } 558 \\
\text { (Declarado } \\
\text { inexequible } \\
\text { por la Corte } \\
\text { Constitucional } \\
\text { en Sentencia C } \\
258 \text { de 2020) }\end{array}$ & $\begin{array}{l}\text { abril } 15 \\
\text { del } 2020\end{array}$ & $\begin{array}{l}\text { Por el cual se implementan } \\
\text { medidas para disminuir } \\
\text { temporalmente la cotización al } \\
\text { Sistema General de Pensiones, } \\
\text { proteger a los pensionados bajo la } \\
\text { modalidad de retiro programado y } \\
\text { se dictan otras disposiciones en el } \\
\text { marco del Estado de Emergencia } \\
\text { Económica, Social y Ecológica. }\end{array}$ & $\begin{array}{l}\text { Disminuir temporalmente la } \\
\text { cotización al Sistema General } \\
\text { de Pensiones, proteger a los } \\
\text { pensionados bajo la modalidad } \\
\text { de retiro programado y se } \\
\text { dictan otras disposiciones } \\
\text { en el marco del Estado de } \\
\text { Emergencia Económica, Social } \\
\text { y Ecológica. }\end{array}$ \\
\hline
\end{tabular}




\begin{tabular}{|c|c|c|c|}
\hline $\begin{array}{l}N^{\circ} \text { del Decreto } \\
\text { Legislativo }\end{array}$ & $\begin{array}{c}\text { Fecha de } \\
\text { expedición }\end{array}$ & Objeto & Medida de protección \\
\hline Decreto 565 & $\begin{array}{c}\text { Abril } 15 \text { de } \\
2020\end{array}$ & $\begin{array}{l}\text { Se adoptan medidas para } \\
\text { garantizar el goce oportuno de } \\
\text { la anualidad vitalicia BEPS como } \\
\text { medio de vida fundamental } \\
\text { para enfrentar la crisis sanitaria } \\
\text { y económica, especialmente } \\
\text { para garantizar que los adultos } \\
\text { mayores, cuenten con un ingreso } \\
\text { que les permita proveer lo } \\
\text { necesario para su subsistencia, } \\
\text { en el marco de la emergencia } \\
\text { producida por la pandemia del } \\
\text { CovID-19. }\end{array}$ & $\begin{array}{l}\text { Ingreso al adulto mayor, que les } \\
\text { permita proveer lo necesario } \\
\text { para su subsistencia, en el } \\
\text { marco de la emergencia } \\
\text { producida por la pandemia del } \\
\text { COVID-19. }\end{array}$ \\
\hline Decreto 659 & $\begin{array}{l}\text { Mayo } 13 \\
\text { de } 2020\end{array}$ & $\begin{array}{l}\text { Se autoriza la entrega de } \\
\text { una transferencia monetaria } \\
\text { no condicionada, adicional y } \\
\text { extraordinaria en favor de los } \\
\text { beneficiarios de los programas } \\
\text { Familias en Acción, Protección } \\
\text { Social al Adulto Mayor - Colombia } \\
\text { Mayor y Jóvenes en Acción. } \\
\text { De igual forma indica que } \\
\text { hay exención de impuestos y } \\
\text { gravámenes financieros para } \\
\text { las operaciones financieras que } \\
\text { impliquen la dispersión de las } \\
\text { transferencias monetarias no } \\
\text { condicionadas antes mencionadas. }\end{array}$ & $\begin{array}{l}\text { Transferencia monetaria favor } \\
\text { de los beneficiarios de los } \\
\text { programas Familias en Acción, } \\
\text { Protección Social al Adulto } \\
\text { Mayor - Colombia Mayor y } \\
\text { Jóvenes en Acción }\end{array}$ \\
\hline
\end{tabular}

Decreto 802

(Declarado

inexequible

por la Corte

Constitucional

en Sentencia C

308 de 2020)
Por el cual se modifica el Decreto Legislativo 558 del 15 de abril de

Junio 4 del 2020 y se dictan otras

2020 disposiciones en el marco del Estado de Emergencia Económica, Social y Ecológica.
Estableció que los traslados de mesada de retiro programado no podían ser obligatorios, sino voluntarios.
Decreto 814

(Declarado exequible por la Corte Constitucional Junio 04 del 2020 en Sentencia C-404/20
" Autoriza al Gobierno nacional para que por medio del Ministerio del Trabajo y del Departamento Administrativo para la Prosperidad Social, realicen en favor de los beneficiarios de los programas Familias en Acción, Protección Social al Adulto Mayor - Colombia Mayor y Jóvenes en Acción entregas de transferencias monetarias no condicionadas, adicionales y extraordinarias."

Por el cual se adiciona el Capítulo 14 al Título 13 de la Parte 2 del

Decreto 1174 Agosto 27 del 2020
Libro 2 del Decreto 1833 de 2016 .

a efectos de reglamentar el Piso de Protección Social.
Transferencias monetarias a los programas de Familias en Acción, Protección Social al Adulto Mayor - Colombia Mayor y Jóvenes en Acción.
Reglamenta el piso mínimo de protección social para aquellas personas que mensualmente perciban ingresos inferiores a un Salario Mínimo Legal Mensual Vigente como consecuencia de su dedicación parcial a un trabajo u oficio o actividad económica. 
Entre los Decretos más controversiales, se encuentra el Decreto Legislativo 558 de abril 15 de 2020, el cual prescribió en el Capítulo II, el denominado Mecanismo especial de pago para las pensiones reconocidas bajo la modalidad de retiro programado (Presidente de la República, 2020), el cual prescribía que:

“(...) Las Sociedades Administradoras de Fondos de Pensiones y Cesantías deberán trasladar a Colpensiones, en un plazo no mayor a cuatro (4) meses, los recursos o activos del Fondo Especial de Retiro Programado y la información correspondiente a los pensionados que a la fecha expedición de este decreto presenten una descapitalización en sus cuentas. (...)

Artículo 7. Mecanismo Especial de Pago. En el evento en que no haya sido posible la contratación de una renta vitalicia en favor aquellos pensionados en la modalidad de retiro programado cuyos saldos ya no resultan suficientes para continuar recibiendo una mesada de un salario mínimo en modalidad, la pensión seguirá pagándose a través de Colpensiones, y tendrá las mismas características de una renta vitalicia, (...)" (Presidente de la República, 2020).

El Gobierno Nacional argumentó que el Capítulo 2 del anterior Decreto era "con el fin de garantizar el aseguramiento del riesgo financiero exacerbado por el Coronavirus y proteger a los pensionados bajo la modalidad de retiro programado de una posible descapitalización de las cuentas individuales de ahorro pensional que soportan el pago de sus mesadas" (Presidente de la República, 2020)

El artículo 12 del Decreto 832 de 1996 establece que "en los términos del artículo 81 de la Ley 100 de 1993, las AFP que ofrezcan el pago de pensiones bajo la modalidad Retiro Programado, deben controlar permanentemente que el saldo de la cuenta de ahorro individual, no sea inferior a la suma necesaria para adquirir una póliza de Renta Vitalicia, mientras el afiliado disfruta de una pensión pagada bajo tal modalidad(...)" (Presidente de la República, 1996); no obstante se temió que ante la contingencia el monto de algunas cuentas hubieran sido insuficientes para adquirir este seguro, adicionando que no hay compañías de seguros interesadas en contratarlas con las AFP.

Según informe de la Superintendencia Financiera de Colombia el número de pensionados bajo la modalidad de retiro programado que tiene las Administradoras de Fondos de pensiones son: 
Tabla 13. Pensionados bajo la modalidad de retiro programado.

\begin{tabular}{lcccccc}
\hline \multirow{2}{*}{ Fondo } & \multicolumn{6}{c}{ Vetiro programado } \\
\cline { 2 - 7 } & \multicolumn{7}{c}{$\boldsymbol{H}$} & $\mathbf{M}$ & $\boldsymbol{H}$ & $\mathbf{M}$ & $\boldsymbol{H}$ & $\mathbf{M}$ \\
\cline { 2 - 7 } & 13232 & 12669 & 5042 & 3677 & 8026 & 2669 \\
\hline Protección & 11911 & 14668 & 1333 & 610 & 3297 & 679 \\
\hline Porvenir & 1759 & 931 & 86 & 67 & 272 & 78 \\
\hline Old mutual & 134 & 12 & 2 & 0 & 10 & 0 \\
\hline $\begin{array}{l}\text { Old mutual } \\
\text { alternativo }\end{array}$ & 6564 & 6653 & 1070 & 620 & 3388 & 747 \\
\hline Colfondos & $\mathbf{3 3 6 0 0}$ & $\mathbf{3 4 9 3 3}$ & $\mathbf{7 5 3 3}$ & $\mathbf{4 9 7 4}$ & $\mathbf{1 4 9 9 3}$ & $\mathbf{4 1 7 3}$ \\
\hline Total & \multicolumn{7}{c}{ Invalidez } & \multicolumn{1}{c}{ Sobrevivientes } \\
\hline Fuente: Informes presentados por las AFP F.495 \\
\hline
\end{tabular}

Fuente: superintendencia financiera de Colombia, 2020

En consecuencia, bajo esta modalidad se encuentran 100.206 personas, lo que representa más de la mitad de los afiliados en el RAIS.

El valor del Fondo Especial de Retiro Programado a marzo 26 de 2020 según datos de la Superintendencia Financiera de Colombia es:

Tabla 14. Valor del Fondo Especial de Retiro Programado.

\begin{tabular}{lcc}
\hline Fondo retiro programado & Enero & Febrero \\
\hline Protección & 13.224 .413 & 13.284 .041 \\
\hline Porvenir & 7.631 .227 & 7.642 .190 \\
\hline Skandia & 2.221 .562 & 2.222 .036 \\
\hline Colfondos & 4.917 .301 & 4.929 .717 \\
\hline Total & $\mathbf{2 7 . 9 9 4 . 5 0 3}$ & $\mathbf{2 8 . 0 7 7 . 9 8 5}$ \\
\hline Fuente: Informes presentados por las AFP. & \\
\hline
\end{tabular}

Fuente: Superintendencia Financiera de Colombia, 2020.

No obstante, la Corte Constitucional en sentencia C 258 del 2020, declaró inexequible el Decreto Legislativo 558, por cuanto estableció que las medidas de excepción adoptadas implican una desmejora de derechos sociales, disponen de recursos destinados a la financiación de las pensiones para fines distintos a ellas, no asegura la sostenibilidad financiera, no satisface los requisitos de conexidad material y de motivación suficiente (julio 23 de 2020, M.P. Antonio José Lizarazo Ocampo).

Luego, se encuentra el Decreto 1174, por el cual se reglamenta el acceso y operación del Piso de Protección Social para aquellas personas que mensualmente perciban ingresos inferiores a un Salario Mínimo Legal Mensual Vigente como consecuencia de su dedicación parcial a un trabajo u oficio o actividad económica; en su Artículo 2.2.13.14.1.4., expone lo que se debe entender como trabajo por tiempo parcial: 
“(...) aquel que desempeña un trabajador que labora por períodos inferiores a un mes calendario o menos de la jornada diaria máxima legal."

En su Artículo 2.2.13.14.5.5., prescribe:

“(...)Los empleadores que tengan personal que desarrolle trabajo por tiempo parcial, que en virtud de ello reciban un ingreso mensual inferior a un (1) Salario Mínimo Legal Mensual Vigente, y que tienen la obligación de vincularlos al Piso de Protección Social, podrán afiliarse y cotizar mensualmente al Sistema General de Seguridad Social en su componente contributivo pagando el total de la contribución, por mínimo un (1) Salario Mínimo Legal Mensual Vigente, lo cual lo exonera de la obligación de vincularse al Piso de Protección Social".

Es controversial en la medida que, antes de las reglas planteadas en el Decreto 1174, en Colombia las personas que se encuentren laborando por días, deben cotizar por semanas, siendo esta una modalidad para efectuar la contribución y pago de los aportes a la seguridad por fracciones semanales, esto permite la vinculación a los sistemas de pensiones, riesgos laborales y subsidio familiar de las personas que trabajan por periodos inferiores a un mes y que devenguen menos de un salario mínimo mensual legal vigente; esto les permite acceder a los beneficios económicos que otorgan los sistemas de pensiones y riesgos laborales.

En consecuencia, se debe pagar al sistema de pensiones conforme a los días laborados, de la siguiente forma:

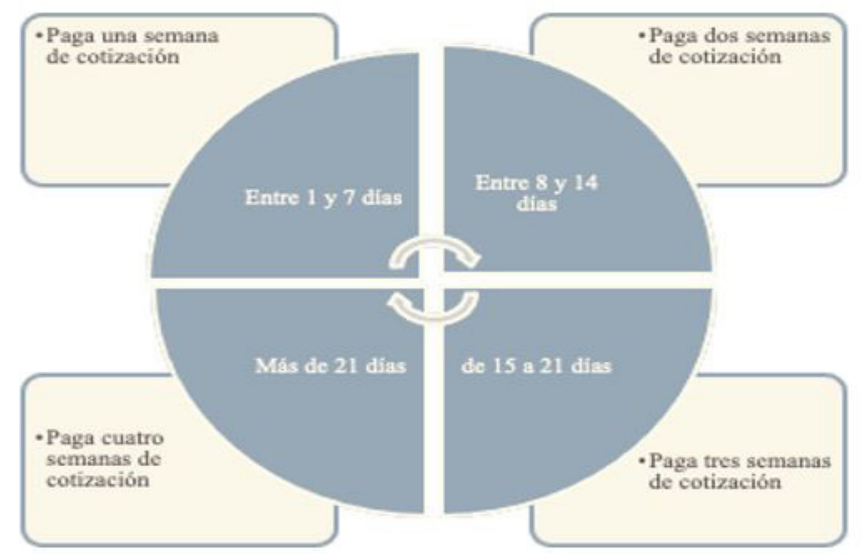

Figura 3. Número de días realmente pagados.

Fuente: elaboración propia a partir de rastreo normativo.

Es temeraria esta forma de pago en la medida que, si la persona registra en el sistema que laboró tres (3) días en el mes, en su historia laboral emitida por su administradora de fondo de pensiones, le aparecerá solo 3 días cotizados, aunque hubieran pagado siete (7) días, no se tiene en cuenta el pago real sino los días reportados como laborados; no obstante, aunque sea temeraria, las persona se encuentra cotizando al sistema de pensiones y eso les da expectativa legítima de acceder a los beneficios económicos que ofrece el sistema pensional en Colombia, expectativa 
que se estaría eliminando si se redireccionan a ese trabajador al denominado Piso de Protección Social. El Decreto se encuentra demandado ante el Consejo de Estado, se llegara a declarar su nulidad, se estaría priorizando la falacia de cobertura, que consiste en aumentar la cifra de afiliados al sistema, en vez de la protección efectiva en materia pensional, que consiste la protección real ante la contingencia de la vejez, enfermedad o muerte.

En últimas, los Decretos expedidos por el Gobierno, evidencian la imposibilidad de ambos regímenes pensionales de cumplir los postulados constitucionales y las pretensiones económicas de la vejez en Colombia, el RPM por su déficit pensional y el RAIS por la ausencia de beneficios reales a sus afiliados a la hora de ser beneficiarios de una pensión de vejez, luego, dados Decretos pretenden desarrollar un modelo de protección especial a la vejez que el Gobierno Nacional ha planteado desde el Plan Nacional de Desarrollo 2018 - 2022 "pacto por Colombia, pacto por la equidad", el denominado "piso mínimo de protección social" (Congreso de la República, 2019), debido y con base a las recomendaciones, de instituciones públicas y privadas, referentes a una reforma pensional, entre ellas: Banco Interamericano de desarrollo- BID, Organización para la Cooperación y el Desarrollo Económico- OCDE, Centro de Estudios Económicos -ANIF, Fundación para la educación Superior y el desarrollo- Fedesarrollo, Asociación Colombiana de Administradoras de Fondos de pensiones y de Cesantía- Asofondos, Ministerio de trabajo y Escuela Nacional Sindical; siendo acogida la propuesta de reforma pensional de la Fundación para la educación Superior y el desarrollo (Fedesarrollo, 2011), esta propuesta se basa en el concepto de Sistema Multipilar, desarrollado por el Banco Mundial (1994) con el fin de establecer un pilar de reducción de la pobreza, con prestaciones económicas de un salario mínimo legal mensual vigente, como límite máximo.

Por tanto hasta la fecha las medidas adoptadas no protegen de forma integral a la vejez en Colombia y ante la contingencia de la COVID -19 es evidente que el Sistema de Seguridad Social no aborda una protección integral para las personas mayores, debido a ello, las consecuencias sociales y económicas producto del nuevo virus, revictimizan a un sector de la población que ya de por sí se encontraba en un estado de vulnerabilidad, siendo necesario repensar un sistema que realmente esté interesado en satisfacer sus necesidades mínimas.

\section{A modo de conclusión}

La pensión de vejez ha tenido una evolución historia entorno a los instrumentos internacionales y las reformas legales que se han surtido especialmente desde 1967 hasta el año 2013, no obstante las cifras del DANE, FASECOLDA y la Superfinanciera de Pensiones de Colombia evidencian que no ha sido suficiente un marco regulatorio para proteger a las personas mayores ya que el acceso a la prestación económica cada vez es más nugatoria y por tanto se requiere de un protección mayor por parte del Estado en esta etapa de la vida.

No hay una planeación realmente estratégica en pro de salvaguardar los derechos fundamentales de las personas mayores en Colombia. Un país como Colombia que se proclama, social de derecho, debe de asumir el rol que se adjudica. Esta especial protección a la vejez, se fundamenta en el mandato Constitucional de lograr una igualdad real y efectiva, lo que implica la adopción de medidas eficientes y eficaces a favor de las personas mayores, deber consagrado en el artículo 46 superior, según el cual es deber del Estado, de la sociedad y de la familia proteger y ayudar a la persona mayor. 
Desde el punto de vista social, hay una realidad, la cual es el envejecimiento humano y el crecimiento exponencial del mismo, cada día son más los individuos que ingresan al círculo de la vejez, seres humanos que en un gran porcentaje se encuentran en estado de debilidad y que son acreedores de derechos que al mismo tiempo son vulnerados por los constantes cambios normativos en materia de pensión de vejez; la vulneración de dados derechos por parte de la normatividad colombiana tiene como consecuencia, una población con más probabilidades de pobreza, analfabetismo y enfermedad.

No se puede limitar la protección a la vejez a la garantía de una pensión de vejez, sería ello discriminar a un alto porcentaje de ciudadanos colombianos que no tuvieron la oportunidad de ingresar al sistema o estar en él, el tiempo suficiente como para tener un beneficio a una prestación económica de vejez.

En necesario crear un sistema de protección social que realmente satisfaga las necesidades mínimas de la vejez en Colombia en consonancia con nuestros postulados y desarrollos constitucionales; se debe implementar un sistema no contributivo que ofrezca garantías reales para la población Colombia que no solamente trabaja de manera formal sino informal y que contribuyen en alguna medida al crecimiento económico del país.

\section{Referencias}

Aristóteles, 1355 b. Retórica. Madrid, España: Editorial Gredos, 1999. Recuperado a partir de: http://www.pdfhumanidades.com/sites/default/files/apuntes/ ARISTO\%CC\%81TELES\%20-\%20Reto\%CC\%81rica\%20\%28Gredos\%2C\%20Madrid\%2C\%201999\%29.pdf

ASOFONDOS, 2020. https://www.asofondos.org.co/wp-content/uploads/2020/04/ Sobre-Decreto-558-y-cuestionamientos-fondos-de-pensiones-Comunicado-abril-22-Final.pdf

Banco Mundial (1994): http://white.lim.ilo.org/spanish/260ameri/oitreg/activid/ proyectos/actrav/proyectos/proyecto ssos/act subregionales/paises andinos/documentos/23 26 mayo2011/notaresumen informebandomundial.pdf

Cardona, Estrada, \& Agudelo. (2006). Calidad de vida y condiciones de salud de la población adulta mayor de Medellín. Biomédica, 26(2), 206-215. Retomado de https://doi.org/10.7705/biomedica.v26i2.1410

Constitución Política de Colombia, 1886.

Constitución del Imperio (REICH) alemán, de 11 de agosto de 1919

Congreso de la República de Colombia. Ley 29 de 1905 (1905). Diario Oficial. No 12343 del 06 de mayo, 1905.

Congreso de la República de Colombia. Ley 23 de 1912 (1912). Diario Oficial. No 14726 del 24 de octubre, 1912.

Congreso de la República de Colombia. Ley 82 de 1912 (1912). Diario Oficial. No 14.751 del 23 de noviembre, 1912. 
Congreso de la República de Colombia. Ley 75 de 1925 (1925). Diario Oficial. No 20.053. del 20 de noviembre, 1925

Congreso de la República de Colombia. Ley 102 de 1927 (1927). Diario Oficial No 2.655, de 28 de noviembre de 1927.

Congreso de la República de Colombia. Ley 6 de 1945 (1945). Diario Oficial No 25.790, del 14 de marzo de 1945

Congreso de la República de Colombia. Ley 90 de 1946 (1946). Diario Oficial No 26.322, del 7 de enero de 1947

Congreso de la República de Colombia. Ley 33 de 1985 (1985). Diario Oficial No. 36.856 de 13 de febrero de 1985

Congreso de la República de Colombia. Ley 71 de 1988 (1988). Diario Oficial No. 38.624 de 22 de diciembre de 1988

Congreso de la República de Colombia. Ley 100 de 1993 (1993). Diario Oficial No. 41.148 de 23 de diciembre de 1993

Congreso de la República de Colombia, Ley 797 de 2003 (2003). Diario Oficial No. 45.079 de 29 de enero de 2003

Congreso de la República, 2019. Plan Nacional de Desarrollo, 2018 - 2022. "pacto por Colombia, pacto por la equidad"

Corominas, Breve diccionario etimológico de la lengua castellana, 2005. Recuperado a partir de: http://etimologias.dechile.net/

Correa Montoya, L., Rodríguez Parra, L., Suárez Ángel, C., \& Rúa Serna, J. (2018, Julio 4). El olvido del derecho.

Corte Constitucional. Sentencia T 398 de 2013, M.P. Jorge Ignacio Pretelt Chaljub.

Fundación para la educación Superior y el desarrollo - Fedesarrollo (https://www. fedesarrollo.org.co/sites/default/files/4imlabrilweb.pdf)

Galeano, B. (2020, marzo). Fenomenología de la seguridad social.

Ministerio de Trabajo, Decreto 3041 de 1966 (1966). Diario Oficial No 32.126, del 14 de enero de 1967.

Ministerio de Trabajo y Seguridad Social, Decreto 758 de 1990 (1990). Diario Oficial No 39.303, de 18 de abril de 1990.

Ministerio de Tecnologías de la Información y las Comunicaciones, 2020. Portal de datos abiertos del Gobierno Nacional. Recuperado a partir de https://www. datos.gov.co/Salud-y-Protecci-n-Social/Cantidad-de-pensionados-de-Colpensiones-por-tipo-d/gnut-8jsz/data 
Ministerio de Tecnologías de la Información y las Comunicaciones, 2020. Portal de datos abiertos del Gobierno Nacional. Recuperado a partir de https://www. datos.gov.co/Salud-y-Protecci-n-Social/N-mero-de-pensionados-de-Colpensiones-por-rango-sa/auvp-x3hv

Organización Mundial de la salud, 2020. Recuperado a partir de: https://www.who. int/csr/disease/swineflu/frequently_asked questions/pandemic/es/

OMS | Envejecimiento. (2021). WHO; World Health Organization. https://www.who. int/topics/ageing/es/

Presidente de la República. Decreto 2351 de 1948 (1948). Diario Oficial No 26.774, de 22 de julio 1948.

Presidente de la República. Decreto 832 de 1996 (1996). Diario Oficial No 42.785, de 14 de mayo de 1996.

Presidente de la República. Acto Legislativo 1 de 2005 (2005). Diario Oficial No. 45.980 de 25 de julio de 2005.

Ministerio de salud, 2020, Recuperado a partir de: https://www.minsalud.gov.co/ Paginas/Adultos-mayores-representan-el-49-de-las-muertes-por-covid-19en-Colombia.aspx?!D=8449

Presidente de la República. Decreto 417 del 17 marzo de 2020 (2020). Diario Oficial 51.259 del 17 de marzo de 2020.

Presidente de la República. Decreto 458 de marzo 22 de 2020 (2020). Diario Oficial No. 51.264 de 22 de marzo 2020.

Presidente de la República. Decreto 486 de marzo 27 de 2020 (2020). Diario Oficial No. 51.269 de 27 de marzo 2020.

Presidente de la República. Decreto 518 de abril 4 de 2020 (2020). Diario Oficial No. 51.284 de 13 de abril de 2020.

Presidente de la República. Decreto 553 de abril 15 de 2020 (2020) Diario Oficial No. 51.286 de 15 de abril de 2020.

Presidente de la República. Decreto 558 de abril 15 de 2020 (2020). Diario Oficial No. 51.335 de 15 de abril de 2020.

Política Colombiana de Envejecimiento Humano y Vejez, (2015). https://www.minsalud.gov.co/proteccionsocial/promocion-social/Paginas/Politica-Colombiana-de-Envejecimiento-Humano-y-Vejez.aspx

Salazar Guatibonza, Flor Esther, Retornos reales de los fondos privados de pensiones en Colombia, marzo de 2020. 
Santamaría, M. (2010). El sistema pensional en Colombia: retos y alternativas para aumentar la cobertura. Bogotá D.C.: Fedesarrollo. Recuperado a partir de https://www.repository.fedesarrollo.org.co/bitstream/handle/11445/351/ El\%20sistema\%20pensional\%20en\%20Colombia.pdf?sequence=1\&isAllowed =y

Simon Bolivar, discurso de angostura (Angostura, 15 de febrero de 1819. Recuperado a partir de https://storicamente.org/sites/default/images/articles/media/1880/ Bolivar Discurso de Angostura.pdf

Superintendencia Financiera de Colombia. Circular externa 013 de 2012 (2012).

Superintendencia Financiera de Colombia, 2020. Recuperado a partir de https:// www.superfinanciera.gov.co/jsp/9110

Superintendencia Financiera de Colombia, 2020. Documento técnico comparativo de metodologías de cálculo de la rentabilidad nominal y real para las administradoras de fondos de pensiones en Colombia.

Superintendencia Financiera de Colombia, 2020. https://www.superfinanciera. gov.co/inicio/informes-y-cifras/cifras/pensiones-cesantias-y-fiduciarias/informacion-por-sector-/pensiones-y-cesantias/regimen-de-ahorro-individual-con-solidaridad-/fondos-de-pensiones-obligatorias/valor-del-fondo-9125

Uribe García, José Ignacio. Ensayos de economía aplicada al mercado laboral. Cali: Universidad del Valle, 2006. 422 p. 